\title{
Perubahan Masyarakat Desa Wisata Bejiharjo pada Tahun 2010-2015
}

\author{
Akhmad Rofiq \\ Program Studi Pendidikan Luar Sekolah, Fakultas Keguruan dan Ilmu Pendidikan, Universitas \\ Sriwijaya. Jalan Raya Palembang Prabumulih Km 32, Indralaya, Ogan Ilir, Indonesia \\ Email: akhmadrofiq91@gmail.com
}

Received: 15 July 2016; Revised: 28 Februar 2017; Accepted: 1 March 2017

\begin{abstract}
Abstrak
Penelitian ini bertujuan untuk menjelaskan: (1) perubahan masyarakat yang terjadi di Desa Wisata Bejiharjo, (2) dampak yang timbul dari kegiatan pariwisata di Desa Wisata Bejiharjo, dan (3) faktor yang mempengaruhi perubahan masyarakat yang terjadi di Desa Wisata Bejiharjo. Penelitian ini mengacu pada metode kualitatif fenomenologi. Langkah dalam analisis datanya sebagai berikut: (a) Menyimak narasi dalam transkip, (b) Melacak data yang penting, (c) Merumuskan makna, (d) Mengelompokkan makna dalam tema-tema, (e) Memadukan semua kelompok tema dalam sebuah penjelasan yang mengungkap pandangan partisipan terhadap fenomena, (f) Mengidentifikasi struktur pokok tema, dan (g) member check. Hasil penelitian menunjukkan bahwa: (1) perubahan masyarakat terjadi dalam aspek ekonomi, sosial, budaya dan pendidikan masyarakat Desa Bejiharjo, (2) dampak yang timbul adalah adanya peningkatan kesejahteraan masyarakat dan kualitas sumber daya manusianya, namun dalam aspek sosial muncul berbagai potensi konflik, serta meningkatnya kriminalitas dan pergaulan bebas, dan (3) faktor yang mempengaruhi perubahan masyarakat berasal dari dalam dan luar masyarakat.
\end{abstract}

Kata Kunci: perubahan masyarakat, desa wisata

\section{Community Changes in Bejiharjo Tourist Village in Year 2010-2015}

\begin{abstract}
This research aims to explain: (1) the community changes that occur in Bejiharjo tourist village, (2) the impact from the tourism activities in Bejiharjo tourist village, and (3) the factors that affect the community changes in Bejiharjo tourist village. The research is based on qualitative phenomenology method. The steps of data analyzing are: (a) reviewing narration on transcript, (b) tracking the important data, (c) formulating meaning, (d) grouping meaning in themes, (e) blending all groups of the themes in an explanation that reveals view of participants to phenomena, $(f)$ identifying basic structure theme, and $(g)$ member check. The research results show that (1) community changes can be seen from economic, social, culture, and education changes in Bejiharjo village, (2) the impact from community change is improvement of social welfare and the quality of human resources, but in social aspect arise various potential conflicts, and (3) factors that infuence the community change come from inside and outside.
\end{abstract}

Keywords: community changes, tourist village

How to Cite: Rofiq, A. (2017). Perubahan masyarakat Desa Wisata Bejiharjo pada tahun 2010-2015. Jurnal Pendidikan dan Pemberdayaan Masyarakat, 4(1), 1-12. doi:http://dx.doi.org/10.21831/jppm.v4i1.10035

Permalink/DOI: http://dx.doi.org/10.21831/jppm.v4i1.10035 


\section{Jurnal Pendidikan dan Pemberdayaan Masyarakat, 4 (1), March 2017 - 2}

Ahmad Rofiq

\section{PENDAHULUAN}

Pada dasarnya setiap masyarakat yang ada di muka bumi ini dalam hidupnya dapat dipastikan akan mengalami apa yang dinamakan dengan perubahan. Adanya perubahan tersebut akan dapat diketahui bila dilakukan suatu perbandingan dengan menelaah suatu masyarakat pada masa tertentu yang kemudian dibandingkan dengan keadaan masyarakat pada waktu yang lampau. Perubahan yang terjadi di dalam masyarakat, pada dasarnya merupakan suatu proses yang terus menerus, ini berarti bahwa setiap masyarakat kenyataannya akan mengalami perubahan-perubahan. All societies change continuously. New traits appear through discovery and invention, or through diffusion from other societies (Horton, 1980, p.474).

Seiring dengan perkembang zaman, perubahan yang terjadi di dalam masyarakat pun semakin komplek. Secara perlahan namun pasti, masyarakat dituntut untuk bisa mengikuti era perubahan yang begitu cepat, mengingat jika tidak mampu untuk mengikuti perubahan maka masyarakat akan semakin terkucilkan. Perubahan sejatinya adalah untuk merubah kondisi dari yang kurang baik menuju ke arah yang lebih baik, akan tetapi sering dijumpai pada masyarakat terjadi perubahan ke arah yang kurang baik, sehingga harapan menjadikan masyarakat sebagai tumpuan dalam meningkatkan kesejahteraan justru terkadang menjadi sebaliknya. Hal ini terlihat dari berbagai permasalahan-permasalahan yang dihadapi oleh masyarakat saat ini, misalnya kehidupan yang masih di bawah garis kemiskinan, kehidupan yang semakin konsumtif, kurangnya keterampilan dalam mengolah sumber daya dan potensi, hingga permasalahan lain yang timbul akibat adanya perubahan dalam masyarakat.

Perubahan yang terjadi dalam masyarakat tidak terlepas dari peran sumber daya yang ada, seperti sumber daya manusia, sumber daya alam mapun sumber daya sosial yang ada di sekitar masyarakat turut berperan serta mendorong proses terjadinya perubahan masyarakat. Apabila sumber daya masyarakat yang ada dapat dioptimalkan, maka perubahan ke arah pembangunan masyarakat akan terjadi. Salah satunya seperti yang mulai diterapkan di Daerah Istimewa Yogyakarta dengan upaya pengoptimalan sumber daya ataupun potensi yang ada di masyarakat untuk dikemas menjadi daya tarik wisata masyarakat yang lebih luas, sehingga sumber daya yang sebelumnya tidak dimanfaatkan saat ini mulai dimanfaatkan untuk membangun masyarakat ke arah yang lebih baik.

adanya sumber daya yang ada, maka proses pemberdayaan masyarakat dapat berjalan bermodalkan sumber daya yang ada di masyarakat, baik sumber daya manusia, alam, maupun sosial. Pemberdayaan pada hakekatnya mencakup dua aspek yaitu, to give or authority dan to give ability to enable. Dalam pengertian pertama, pemberdayaan memiliki makna memberi kekuasaan, sedangkan dalam pengertian kedua, pemberdayaan diartikan sebagai upaya untuk memberi kemampuan atau keberdayaan, (Suparjan, 2003, pp.42-43). Pemberdayaan juga merupakan kunci untuk meningkatkan kualitas kehidupan masyarakat hal ini sejalan dengan disampaikan oleh Narayan yaitu: Empowermen is key for: (a) Quality of life and human dignity, (b) good governance, (c) Pro-poor growth dan, (d) Project effectiveness (Narayan, 2002, p. 8). Konsep pemberdayaan sebenarnya tidak sekedar merupakan proses belajar yang menekankan pada orientasi dari proses serta pelibatan masyarakat. Hasil yang diharapkan dari proses pemberdayaan melalui pendidikan nonformal ini adalah tumbuhnya kesadaran dan kompetensi serta tanggung jawab sosial dan kapasitas masyarakat untuk membangun masa depan kehidupan yang lebih baik. (Miradj \& Sumarno, 2014, p. 106).

Berbicara mengenai kepariwisataan DIY, tentunya tidak terlepas dari destinasi wisata yang ada. Dari beragam macam destinasi wisata yang meliputi objek wisata alam, objek wisata budaya, objek wisata buatan, serta desa/kampung wisata yang ditawarkan, Kabupaten Gunungkidul menjadi kabupaten/kota di DIY yang jumlah kunjungan wisatawannya memiliki peningkatan prosentase paling banyak. Hal ini terlihat dari banyaknya wisata alam yang ditawarkan oleh Kabupaten yang dikenal 


\section{Jurnal Pendidikan dan Pemberdayaan Masyarakat, 4 (1), March 2017 - 3}

Ahmad Rofiq

dengan kota seribu gunung (gunung sewu). Adapun potensi wisata alamnya yang meliputi wilayah pantai seperti Pantai Baron, Pantai Sadranan, Pantai Wediombo, Pantai Siung dan sebagainya. Selain itu terdapat wisata minat khusus yang ditawarkan seperti Tracking Gunung Api Purba Nglanggeran, Cave Tubing Pindul, Body Rafting Kali Oya, Air Terjun Sri Gethuk, Goa Jomblang dan masih banyak lagi wisata minat khusus lainnya.

potensi alam yang dimiliki, tidak heran Gunungkidul menjadi hidden paradise yang saat ini mulai digandrungi oleh berbagai wisatawan baik dalam maupun luar negeri untuk menjadi daerah tujuan wisata. Pada saat ini yang mengalami perkembangan di masyarakat adalah wisata alam yang dikelola sendiri oleh masyarakat atau yang dikenal dengan pariwisata berbasis masyarakat (community based tourism), seperti halnya di Desa Wisata Bejiharjo.

Pengelolaan potensi alam di Desa Bejiharjo yang dimulai pada 30 Juni 2010 oleh Pokdarwis Dewa Bejo dengan menerapkan pola pemberdayaan masyarakat mampu membuka lapangan pekerjaan yang lebih luas. Berbagai macam kegiatan usaha pendukung wisatawan mulai berjalan seiring dengan berkembangnya kawasan wisata ini, sehingga dengan kondisi tersebut memberikan arah perubahan kehidupan masyarakat yang pada awalnya bekerja di sektor pertanian mulai bergeser pada sektor pariwisata. Tentunya fenomena perubahan masyarakat yang terjadi begitu cepat ini menjadi tanda tanya terkait kesiapan masyarakat menghadapi era pariwisata yang sangat heterogen dan komplek.

realita, tidak jarang wisata alam yang ada dan dikelola masyarakat kurang dapat memberikan manfaat yang besar terhadap kemajuan masyarakat karena minimnya keterlibatan serta pola pemberdayaan masyarakat yang dilakukan oleh pengelola wisata. Hal ini disebabkan karena seringkali ada kepentingan pribadi dalam upaya pengelolaan wisata, sehingga menyebabkan kondisi yang tidak harmonis dalam kehidupan masyarakat. Selain itu masalah budaya asing yang dibawa oleh wisatawan seringkali dapat mempengaruhi gaya hidup masyarakat sekitar wilayah objek wisata yang kurang sesuai dengan kebudayaan asli masyarakat. Selanjutnya kehidupan masyarakat wisata yang cenderung keras dapat mengubah pola kehidupan masyarakat desa yang identik dengan kehidupan penuh toleransi dan gotongroyong dapat berubah.

keberadaan kegiatan wisata yang ada diharapkan untuk meningkatkan kesejahteraan masyarakat, namun fenomena perubahan masyarakat yang terjadi seringkali dapat menimbulkan berbagai dampak baik positif maupun negatif. Arah perubahan yang sangat labil tergantung dari berbagai aspek yang mempengaruhi, sehingga kondisi ini bagai dua sisi mata uang yang berbeda. Pada dasarnya fenomena sosial dapat diartikan sebagai gejala-gejala atau peristiwa yang terjadi dan dapat diamati dalam kehidupan sosial. Dari pengertian tersebut dapat dipahami bahwa perubahan masyarakat yang terjadi di masyarakat Desa Wisata Bejiharjo merupakan salah satu bentuk fenomena sosial. Terkait dengan hal tersebut, dipandang penting untuk melakukan penelitian yang berusaha menjelaskan proses perubahan masyarakat, dampak dan faktor yang mempengaruhi perubahan masyarakat yang terjadi di Desa Wisata Bejiharjo.

Suatu perubahan dalam kehidupan masyarakat tidak mungkin berhenti pada satu titik tertentu. Proses perubahan sosial dalam bidang kehidupan tertentu maka di bidang lain akan segera mengikutinya, karena struktur lembaga-lembaga kemasyarakatan sifatnya jalin-menjalin. Perubahan sosial sendiri memiliki bidang yang sangat luas dengan berbagai komponen atau aspek yang dapat terjadi perubahan di dalam kehidupan.

Masyarakat adalah sekumpulan orang yang saling berinteraksi secara kontinyu, sehingga terdapat relasi sosial yang terpola, terorganisasi. Manusia, baik dari sebagai individu maupun sebagai warga masyarakat mempunyai kebutuhan. Dalam kehidupan bermasyarakat, kebutuhan dapat bersifat individual dan kolektif (Soetomo, 2011, p.25). Maka tergambar jelas bahwa dalam masyarakat terdapat pola interaksi yang berlangsung terus-menerus untuk saling berperan dalam kehidupan masyarakatnya. Sehingga 


\section{Jurnal Pendidikan dan Pemberdayaan Masyarakat, 4 (1), March 2017 - 4}

Ahmad Rofiq

dengan adanya interaksi tersebut terjadilah berbagai bentuk perubahan yang disadari maupun tidak disadari.

\section{Masyarakat Desa}

Masyarakat desa sangat identik dengan masyarakat agraris yang menggantungkan hidupnya dari hasil mengolah lingkungan sekitarnya, baik melalui pertanian, perikanan, peternakan dan lain sebagainya. Secara sosial dan budaya masyarakat desa memiliki kehidupan yang homogen, mengingat pola kehidupan masyarakat yang masuh tradisional dengan tingkat pendidikan yang belum begitu baik. Kehidupan masyarakat desa sangat menggantungkan nasibnya pada kekayaan alam untuk memenuhi kebutuhan sehari-hari baik melalui kegiatan pertanian, perikanan, maupun pemanfaatan sumber daya alam lainnya.

Perubahan mungkin berlangsung dalam berbagai jenis kelajuan seperti lambat, sedang, dan cepat, atau secara evolusi maupun revolusi. Di sisi lain adalah hukum alam, bahwa ada reaksi karena ada aksi, ada respons bila ada tantangan, ada perubahan karena ada penyebab. Penyebab perubahan dari dalam masyarakat itu sendiri antara lain sebagai berikut: Bertambah atau berkurangnya penduduk, penemuan baru, pertentangan masyarakat, serta adanya pemberontakan atau revolusi (Soekanto, 2012, p.275). Proses perubahan masyarakat terjadi berakar dari berbagai faktor yang melatar belakanginya. Faktor-faktor penyebab terjadinya perubahan tersebut dapat berasal dari dalam masyarakat itu sendiri maupun dari luar masyarakat yang mengalami perubahan, dengan harapan akan terjadi perubahan yang lebih baik untuk kedepannya.

Pariwisata tetap menjadi primadona dan bahkan menjadi salah satu tumpuan harapan perekonomian Indonesia. Pariwisata dinilai sebagai sektor paling siap bangkit ketika negara sedang mengalami krisis. Pariwisata sendiri adalah suatu kegiatan yang secara langsung menyentuh dan melibatkan masyarakat, sehingga membawa berbagai dampak terhadap masyarakat setempat. Pariwisata adalah berbagai macam kegiatan wisata dan didukung berbagai fasilitas serta layanan yang disediakan oleh masyarakat, pengusaha, pemerintah, dan pemerintah daerah (Dinas Pariwisata DIY, 2010, p.12).

Kegiatan pariwisata harus memperhatikan aspek keberlanjutan yang menekankan pada ecological sustainability, social sustainability, cultural sustainability, and economic sustainability (Hannam \& Knox, 2010, p. 130). Dengan adanya keberlanjutan dalam beberapa aspek tersebut, diharapkan keberlangsungan kegiatan pariwisata juga akan terjaga.

\section{Desa Wisata}

Saat ini banyak wilayah pedesaan di Indonesia yang dikembangkan potensi budaya dan kekayaan alamnya untuk meningkatkan kesejahteraan masyarakatnya melalui bidang pariwisata. Mengingat saat ini banyak wisatawan yang mulai melirik wilayah pedesaan khususnya di Yogyakarta sebagai destinasi pariwisata alternatif bagi para wisatawan baik wisatawan lokal maupun mancanegara.

Yogyakarta is the second tourist destination in Indonesia after Bali. It offers rural tourism as alternative tourist attractions in a natural and cultural heritage scheme which has been the mainstay of the local government. Rural tourism offer the tourist experience into a new way with direct involvement in the daily life of the rural community. The rural tourism is managed by the rural community itself (Herawati, Purwaningsih, Pudianti, \& Surya, 2014, p. 88).

Sektor pariwisata menjadi sektor strategis dalam pengembangan wilayah pedesaan, karena dengan pengembangan melalui bidang pariwisata ini dapat membuka peluang untuk menggairahkan kegiatan perekonomian wilayah pedesaan serta sektor lainnya yang terkait. Setidaknya hal tersebut menjadi peluang bagi masyarakat pedesaan untuk meningkatkan gairah perekonomian wilayahnya melalui kegiatan pariwisata dengan cara mengoptimalkan berbagai potensi yang ada baik potensi budaya maupun potensi alamnya.

Pemberdayaan masyarakat harus membangun masyarakat, dengan melibatkan pengembangan sumber daya masyarakat baik sumber daya alam, sumber daya manu- 


\section{Jurnal Pendidikan dan Pemberdayaan Masyarakat, 4 (1), March 2017 - 5}

Ahmad Rofiq

sia serta modal sosial yang ada di masyarakat. Dengan adanya sinergitas yang dijalin dengan harmonis, maka upaya meningkatkan kondisi masyarakat yang kurang berdaya dapat mengarah ke pembangunan yang lebih baik.

Pada prinsipnya, pemberdayaan masyarakat (people empowerment) dapat juga dimaknai sebagai suatu upaya untuk menguatkan power (daya) atau empowering dari golongan masyarakat yang powerless (tidak berdaya), yaitu biasanya mereka yang sedang tergolong ke dalam masyarakat marjinal. Power dalam artian empowering seperti tadi diartikan sebagai kekuasaan dan kekuatan, sehingga dalam kegiatan pemberdayaan terkandung dua makna yakni suatu proses memberikan/mengalihkan sebagian kekuasaan dan kekuatan dari yang powerful kepada yang powerless (Sunaryo, 2013, p.216).

Empowerment is the expansion of assets and capabilities of poor people to participate ini, negotiate with, influence, control, and hold accountable institutions that effect their lives (Narayan, 2002, p. 12). Pemberdayaan merupakan perluasan aset dan kapasitas orang miskin atau kurang mampu untuk dapat berpartisipasi, bernegosiasi, mempengaruhi, mengontrol, dan memegang lembaga akuntabel yang dapat mempengaruhi kondisi kehidupan mereka.

Kehidupan desa sebagai tujuan wisata adalah desa sebagai objek sekaligus juga sebagai subyek dari kepariwisataan. Sebagai suatu objek maksudnya adalah bahwa kehidupan pedesaan merupakan tujuan bagi kegiatan wisata, sedangkan sebagai subyek adalah bahwa desa dengan segala aktivitas sosial budayanya merupakan penyelenggara sendiri dari berbagai aktivitas kepariwisataan, dan apa yang dihasilkan oleh kegiatan tersebut akan dinikmati oleh masyarakatnya secara langsung. Peran aktif dari masyarakat sangat menentukan dalam kelangsungan kegiatan pariwisata pedesaan. Pelibatan partisipasi masyarakat dalam proyek pengembangan pariwisata dikenal dengan istilah Community Based Tourism (CBT) atau dalam istilah Bahasa Indonesia dikenal dengan Pariwisata Berbasis Masyarakat.

Community Based Tourism (CBT) adalah pariwisata yang menyadari kelangsungan budaya, sosial dan lingkungan. Bentuk pariwisata ini dikelola dan dimiliki oleh masyarakat untuk masyarakat, guna membantu para wisatawan untuk meningkatkan kesadaran mereka dan belajar tentang masyarakat dan tata cara hidup masyarakat lokal. Community Based Tourism bukanlah bisnis wisata yang bertujuan untuk memaksimalkan profit atau keuntungan bagi para investor, melainkan lebih terkait dengan dampak pariwisata bagai masyarakat setempat dan sumber daya lingkungannya (Hadiwijoyo, 2012, p. 71).

Community based Tourism (CBT) refers to local involvement in the planning, development, and management of tourism. It assumes that this local participation has positive effects on both socio economic development and conservation (RuizBallesteros \& Brondizio, 2013, p. 323). CBT sangat erat kaitannya dengan kontribusi masyarakat baik dalam perencanaan, pengembangan dan manajemen kegiatan pariwisata. Dengan adanya kontribusi dan keterlibatan masyarakat dalam kegiatan pariwisata tersebut diharapkan dapat memberikan dampak positif bagi pengembangan sosial ekonomi dan konservasi.

CBT berkaitan erat dengan adanya kepastian partisipasi aktif dari masyarakat setempat dalam pembangunan kepariwisataan yang ada. Partisipasi masyarakat dalam pariwisata terdiri atas dua perspektif; yaitu partisipasi masyarakat dalam proses pengambilan keputusan dan partisipasi yang berkaitan dengan distribusi keuntungan yang diterima oleh masyarakat dari pembangunan pariwisata. Ada tiga prinsip poko dalam strategi perencanaan pembangunan pariwisata berbasis masyarakat, yaitu: (1) mengikutsertakan anggota masyarakat dalam pengambilan keputusan; (2) adanya kepastian masyarakat lokal menerima manfaat dari kegiatan pariwisata; dan (3) pendidikan kepariwisataan bagi masyarakat lokal (Sunaryo, 2013, p.140).

Pariwisata Berbasis Masyarakat era globalisasi ini, sektor pariwisata menjadi salah satu sektor yang menjadi ujung tombak perekonomian masyarakat. Dengan waktu yang singkat, muncul berbagai macam destinasi wisata baru guna menarik 


\section{Jurnal Pendidikan dan Pemberdayaan Masyarakat, 4 (1), March 2017 - 6}

Ahmad Rofiq

wisatawan, baik destinasi wisata alam, buatan, atraksi, ataupun yang lainnya.

Pariwisata juga menyentuh berbagai aspek kehidupan masyarakat seperti politik, keamanan, dan sebagainya, dampak pariwisata yang timbul antara lain: (1) dampak terhadap sosial-ekonomi; (2) dampak terhadap sosial budaya; dan (3) dampak terhadap lingkungan (Pitana \& Gayatri, 2005, p.109). Meskipun terdapat dampak positif yang terjadi, namun dampak negatif juga selalu mengikuti perkembangan di sektor pariwisata.

\section{METODE}

Penelitian ini menggunakan pendekatan kualitatif, karena penelitian ini tidak untuk menguji hipotesis tertentu, akan tetapi menggambarkan apa adanya tentang suatu gejala. Metode yang digunakan dalam penelitian ini adalah kualitatif fenomenogi, karena penelitian kualitatif fenomenologi merupakan penelitian yang dilakukan untuk memperoleh informasi mendalam tentang fenomena maupun pengalaman sosial seseorang seperti sikap, motivasi, kepercayaan, dan perilaku dari sudut pandang orang tersebut. Dengan kualitatif fenomenologi, peneliti harus mampu mengungkap data secara mendalam (in depth) agar dapat mengetahui pola perubahan masyarakat di dewa wisata bejiharjo. In depth dalam penelitian fenomenologi bermakna mencari sesuatu yang mendalam untuk mendapatkan satu pemahaman yang mendetail tentang fenomena sosial dan pendidikan yang diteliti. In-depth juga bermakna menuju pada sesuatu yang mendalam guna mendapatkan sense dari yang nampaknya straight-forward secara aktual potensial lebih complicated. Pada sisi lain peneliti juga harus memformulasikan kebenaran peristiwa/kejadian dengan pewawancaraan mendalam ataupun interview.

Penelitian ini telah dilaksanakan di kawasan Desa Wisata Bejiharjo yang beralamat di Desa Bejiharjo, Kecamatan Karangmojo, Kabupaten Gunungkidul. Peneliti menentukan lokasi penelitian di Desa Wisata Bejiharjo, karena adanya ketertarikan peneliti pada pengembangan potensi alam dengan pariwisata berbasis masyarakat ini sehingga terjadi proses perubahan masyarakat pada tahun 2010-2015 dengan adanya kegiatan wisata di Desa Wisata Bejiharjo. Selain itu kegiatan pariwisata khususnya di wilayah Kabupaten Gunungkidul yang sedang populer saat ini menjadi pertimbangan yang tidak kalah menarik penelitian ini dilaksanan di lokasi di kawasan Desa Wisata Bejiharjo Kecamatan Karangmojo Kabupaten Gunungkidul. Penelitian ini telah dilakukan pada bulan Februari sampai dengan April tahun 2016.

Target/subjek penelitian ini antara lain adalah: (1) tokoh masyarakat Desa Bejiharjo; (2) pengelola Desa Wisata Bejiharjo; dan (3) masyarakat Desa Bejiharjo. Menentukan target/subjek penelitian ini menggunakan criterion-based selection yang didasarkan pada asumsi bahwa subjek tersebut sebagai actor dalam tema penelitian. Sehingga dengan penentuan ini dapat memberikan data yang sesuai dengan apa yang yang terjadi di Desa Bejiharjo dalam kurun waktu tahun 2010-2015.

\section{Data, Intrumen, dan Teknik Pengumpulan Data}

Penelitian fenomenologi ini menggunakan dua sumber data yaitu sumber data primer dan sekunder. Sumber data primer yang di ambil adalah fenomena yang ada di masyarakat Desa Bejiharjo berdasarkan pengamatan yang dikuatkan dengan pernyataan dari informan serta selebihnya adalah data pendukung. Kata-kata dan tindakan yang diamati dan diwawancarai merupakan sumber data utama. Pencatatan sumber data utama melalui wawancara atau pengamatan berperan serta merupakan hasil usaha gabungan dari kegiatan melihat, mendengarkan, dan bertanya. Sumber data primer yang digunakan antara lain, hasil observasi dan wawancara peneliti terhadap tokoh masyarakat, pengelola desa wisata serta masyarakat yang ada di kawasan Desa Wisata Bejiharjo. Sedangkan data sekunder yang digunakan oleh peneliti adalah data berupa arsip terkait dengan kependudukan Desa Bejiharjo, arsip terkait Desa Wisata Bejiharjo dan berbagai arsip serta dokumentasi pendukung lainnya. 


\section{Jurnal Pendidikan dan Pemberdayaan Masyarakat, 4 (1), March 2017 - 7 Ahmad Rofiq}

Proses pengumpulan data, peneliti sebagai instrumen kunci akan berhadapan dengan objek yang diteliti, di mana peneliti bertindak sebagai pengamat sekaligus menjadi anggota di dalamnya. Selain peneliti sebagai instrumen kunci atau utama dalam penelitian, tentunya penelitian ini juga didukung dengan teknik penelitian yang lain seperti teknik observasi, wawancara mendalam, dan dokumentasi. Adapun tujuan dari teknik-teknik tersebut adalah untuk mempermudah peneliti dalam memperoleh data dan pengumpulan data dari hasil penelitian. Dalam penelitian kualitatif kuncinya pada peneliti, karena akan berpengaruh terhadap hasil penelitian itu sendiri.

\section{Teknik Analisis Data}

Penelitian yang akan mengkaji mengenai fenomena perubahan masyarakat di Desa Wisata Bejiharjo ini menggunakan metode dengan langkah-langkah analisis datanya adalah sebagai berikut: (1) menyimak narasi dalam transkip; (2) melacak data yang penting; (3) merumuskan makna; (4) mengelompokkan makna dalam tema-tema; (5) memadukan semua kelompok tema dalam sebuah penjelasan yang mengungkap pandangan partisipan terhadap fenomena; (6) mengidentifikasi struktur pokok yema; dan (7) member check.

\section{HASIL DAN PEMBAHASAN}

Desa Bejiharjo sebelum diresmikan menjadi kawasan wisata dikenal sebagai wilayah dengan penduduk yang mayoritas bermata pencaharian di bidang pertanian dan perantau. Sehingga sektor pertanian benar-benar menjadi salah satu tumpuan untuk menopang kehidupan ekonomi masyarakatnya. Hal ini tentunya berpengaruh terhadap rendahnya kesadaran masyarakat akan pendidikan yang disebabkan karena dilatarbelakangi kurangnya kesejahteraan masyarakat di bidang ekonomi, mengingat biaya sekolah kian hari semakin tinggi sehingga masyarakat mengesampingkan kebutuhan pendidikannya demi memenuhi kebutuhan hidupnya. Dengan keadaan kala itu yang serba terbatas kesempatan kerja di Desa, mendorong masyarakat Desa Bejiharjo untuk mencari peruntungan di perantauan meski hanya sebagai buruh mengingat masih rendahnya tingkat pendidikan masyarakat Desa Bejiharjo.

seiring berjalannya waktu, melihat keadaan masyarakat yang kurang sejahtera, muncul agent of change dari anggota masyarakat yang melihat potensi wilayah di Desa Bejiharjo dari sisi yang berbeda, dengan mencoba mengoptimalkan potensi alam, potensi budaya, serta potensi masyarakat dengan membentuk Kelompok Sadar Wisata Desa Bejiharjo pada 30 Juni 2010 dengan jumlah pengelola sebanyak 11 orang. Dari berbagai bentuk pengembangan yang dilakukan tersebut mampu menjadi titik balik dengan memberikan dampak perubahan masyarakat yang luar biasa, baik dari sisi perubahan pola pikir masyarakat, orientasi kegiatan ekonomi, serta adanya pengembangan potensi wilayah yang sangat pesat dalam kurun waktu tahun 2010-2015.

Keadaan menjadi berubah setelah adanya peresmian kawasan Desa Wisata Bejiharjo pada tahun 2010. Masyarakat Desa Bejiharjo berinisiatif menyediakan segala macam kebutuhan wisatawan, mulai dari munculnya beberapa pokdarwis/sekretariat wisata, membuka usaha kuliner, pakaian, homestay/penginapan, penyediaan fasilitas umum seperti toilet umum, penjaga parkir, pemandu wisata, penyediaan transport lokal hingga membuka wahana pengembangan wilayah sebagai destinasi pendukung di kawasan Desa Wisata Bejiharjo serta masih banyak lagi usaha baru yang ada di masyarakat. Dengan adanya usaha-usaha tersebut mendukung peningkatan pendapatan yang diperoleh masyarakat sehingga meningkatkan kesejahteraan masyarakat Desa Bejiharjo.

Perubahan-perubahan telah banyak terjadi dalam kurun waktu tahun 2010-2015 ini, dari segi fisik terlihat pada perubahan kondisi bangunan rumah saat ini yang mengalami perbaikan daripada sebelum adanya kegiatan wisata di Desa Bejiharjo, tentunya juga dapat menjadi salah satu indikator meningkatnya kesejahteraan masyarakat. Perubahan terkait peningkatan ekonomi sangat dirasakan berkat adanya pengembangan desa menjadi kawasan destinasi wisata. Di kalangan pemuda, yang dulunya belum 


\section{Jurnal Pendidikan dan Pemberdayaan Masyarakat, 4 (1), March 2017 - 8}

Ahmad Rofiq

mempunyai pekerjaan dan cenderung kurang produktif, saat ini mampu diakomodasi untuk bergabung di kelompok sadar wisata atau sekretariat layanan jasa wisata yang ada di kawasan Desa Wisata Bejiharjo, hal tersebut tentunya sebagai wujud pemberdayaan masyarakat yang ada dalam proses pengembangan kawasan Desa Wisata Bejiharjo.

salah satu kawasan Desa Budaya di Daerah Istimewa Yogyakarta, dengan adanya desa wisata ini menjadikan momentum tersendiri untuk terus melestarikan kekayaan budaya yang ada di Desa Bejiharjo. Mengingat dalam kegiatan industri wisata, kebudayaan lokal menjadi komoditas bagi wisatawan yang berkunjung, sehingga dengan adanya kegiatan desa wisata ini memberikan dampak yang positif bagi pelestarian budaya yang ada. Meski banyaknya perubahan yang terjadi di masyarakat, namun potensi di sektor pertanian sampai saat ini terus dikelola oleh masyarakat dengan baik sehingga memberikan penghasilan tambahan bagi masyarakat sekitar. Sehingga dengan peningkatan kesejahteraan masyarakat ini, mampu memberikan dampak yang positif, seperti dengan bertambahnya kesadaran masyarakat akan pentingnya pendidikan dengan banyaknya anggota masyarakat yang mengenyam pendidikan lebih tinggi daripada sebelumnya. Selain itu terdapat pergeseran yang terjadi pada kondisi sosial masyarakat dengan berkurangnya jumlah perantau karena banyaknya anggota masyarakat yang terserap sebagai tenaga dalam kegiatan industri pariwisata yang telah berjalan dari tahun 2010 ini.

Hasil penelitian yang dilakukan menyebutkan bahwa terdapat perubahan dalam aspek ekonomi, sosial, budaya dan pendidikan masyarakat Desa Bejiharjo dengan adanya penerapan konsep pemberdayaan berbasis pariwisata. Selain itu ditemukan berbagai faktor penyebab terjadinya perubahan masyarakat serta dampak yang timbul dari kegiatan pengelolaan wisata yang berlangsung sejak 30 Juni 2010.

Adanya kegiatan industri pariwisata yang berlangsung sejak tahun 2010 tersebut nampak memberikan pengaruh yang besar dalam proses perubahan masyarakat yang terjadi. Perubahan masyarakat yang terjadi meliputi perubahan yang bersifat positif maupun yang bersifat negatif.

data yang diperoleh peneliti, secara umum pola pemberdayaan masyarakat telah berjalan dengan melibatkan seluruh lapisan masyarakat dalam kegiatan wisata yang dikelola secara mandiri oleh masyarakat. Kegiatan pemberdayaan masyarakat ini didukung dengan adanya potensi dan peluang yang ada di kawasan Desa Bejiharjo. Konsep pengembangan wisata menekankan pada pemberdayaan masyarakat mengingat dari awal pembentukan kawasan wisata ini diperuntukkan guna meningkatkan kesejahteraan masyarakat Desa Bejiharjo. Peran agen perubahan sangat terlihat dalam proses pemberdayaan masyarakat ini. Dalam hal ini para perintis kegiatan wisata di Kelompok Sadar Wisata Dewa Bejo menjadi agen perubahan dalam pemberdayaan masyarakat, yang diikuti oleh beberapa kelompok sadar wisata yang muncul saat ini. Upaya penerapan konsep pemberdayaan masyarakat terus berjalan mengingat adanya pelibatan masyarakat di dalam setiap kelompok sadar wisata yang ada.

\section{Aspek Ekonomi}

Secara garis besar, terdapat peningkatan yang signifikan dari segi ekonomi masyarakat, hal ini tidak dipungkiri terjadi karena adanya kegiatan wisata yang mampu memberikan warna baru bagi kehidupan masyarakat. Tidak saja memberikan peluang pekerjaan yang lebih banyak, namun secara langsung berdampak pada peningkatan kesejahteraan masyarakat. Kegiatan wisata di Desa Bejiharjo benar-benar mampu memberikan perubahan pada pola pikir masyarakat yang sebelumnya mayoritas hanya berpegang pada sektor pertanian, namun seiring dengan pengembangan Desa Wisata Bejiharjo ini masyarakat mampu merambah sektor pariwisata untuk mencukupi kebutuhan ekonominya. Meski sektor pariwisata muncul sebagai lahan baru untuk mengais rezeki, namun masyarakat setempat tidak meninggalkan begitu saja sektor pertanian, sehingga keseimbangan antar berbagai sektor tetap terjaga. 
Jurnal Pendidikan dan Pemberdayaan Masyarakat, 4 (1), March 2017 - 9

Ahmad Rofiq

\section{Aspek Sosial}

Banyaknya peluang usaha baru di masyarakat memberikan pengaruh yang tidak selamanya baik. Meskipun dalam aspek ekonomi hal tersebut sangat positif, namun dalam kondisi sosial menjadi kebalikannya, tentunya karena adanya persaingan usaha serta kecemburuan sosial yang terjadi sehingga dapat menjadi potensi konflik di masyarakat. Dengan adanya persaingan usaha dan kecemburuan sosial tersebut sangat memberikan dampak pada kehidupan sosial masyarakat Desa Bejiharjo, sehingga kondisi sosial masyarakat menjadi aspek serius yang harus diperhatikan agar tidak timbul konflik dalam masyarakat yang dapat mengurangi eksistensi kegiatan wisata di Desa Bejiharjo, sehingga diperlukan kesadaran dan pola pikir yang jernih agar mampu meminimalisir potensi negatif tersebut. Keterlibatan seluruh elemen dalam masyarakat sangat diharapkan untuk menepis isu yang ada, sehingga dengan adanya keterlibatan masyarakat untuk saling menjaga dan menghargai maka kondisi sosial masyarakat akan lebih stabil.

\section{Aspek Budaya}

Berbicara mengenai budaya, terdapat fakta bahwa budaya masyarakat yang beberapa tahun yang lalu mulai ditinggalkan, saat ini mulai digandrungi oleh masyarakat karena adanya permintaan dari wisatawan. Hal ini tentunya menjadi momentum yang tepat untuk mendeklarasikan bahwa Desa Bejiharjo merupakan salah satu desa budaya di DIY yang aktif dan eksis dalam pelestarian kebudayaan daerah. Dengan eksistensi Desa Bejiharjo dalam nguri-uri budaya lokal, tentunya akan memberikan nilai lebih yang berdampak pada nilai jual Desa Wisata Bejiharjo di mata wisatawan baik dalam maupun wisatawan mancanegara. Namun kondisi ini harus didukung segala elemen masyarakat yang ada di Desa Bejiharjo, agar benar-benar mampu bersinergi dan mempunyai rasa memiliki untuk melestarikan budaya daerah yang ada. Jika hanya berlandaskan momentum saja, dikhawatirkan proses tersebut tidak akan berlangsung lama dan berkelanjutan.

\section{Aspek Pendidikan}

Sedangkan keadaan pendidikan masyarakat merupakan salah satu dari beberapa aspek yang mengalami peningkatan. Kondisi pendidikan masyarakat mulai membaik dengan semakin tingginya pendidikan formal yang dienyam oleh masyarakat, hal ini didukung dengan kondisi kesejahteraan masyarakat yang meningkat. Selain pendidikan formal, pendidikan nonformal juga mengalami peningkatan yang signifikan, hal ini dilatarbelakangi adanya kebutuhan, sehingga pendidikan berbasis kebutuhan yang pada hal ini pendidikan nonformal, mampu berjalan di Desa Bejiharjo sebagai pendidikan alternatif untuk memenuhi kebutuhan masyarakat. Hal ini tentunya memberikan angin segar pada peningkatan kualitas sumber daya manusia masyarakat Desa Bejiharjo yang akan berdampak pada peningkatan kualitas pola pikir masyarakat dalam menghadapi masalah dan tantangan yang ada.

\section{Analisis Perubahan Masyarakat}

Proses perubahan masyarakat yang terjadi di Desa Bejiharjo merupakan fenomena kehidupan bermasyarakat. Perubahan masyarakat yang terjadi dapat mengarah ke arah yang lebih baik, namun juga dapat menuju hal yang kurang baik. Berbagai hal timbul dari proses perubahan masyarakat yang terjadi. Efek domino akan selalu mengikuti sebagai dampak dari apa yang telah dipilih oleh masyarakat sebagai suatu bentuk usaha memperbaiki kondisi masyarakat. Berbagai bentuk perubahan yang meliputi aspek ekonomi, sosial, budaya dan bahkan pendidikan turut serta memberi warna proses dinamika masyarakat. Ada dampak positif bagi pembangunan kesejahteraan di masyarakat, namun tidak sedikit pula dampak negatif yang muncul karena proses pengembangan wilayah wisata yang ada di Desa Bejiharjo ini.

Hal tersebut juga berlaku di Desa Wisata Bejiharjo, yang mana dari segi positif terdapat berbagai peningkatan kesejahteraan masyarakat, terciptanya peluang usaha, serta pembangunan fasilitas umum yang merata. Namun di sisi lain, dari segi negatif pengembangan Desa Wisata Bejiharjo ini berdampak 
pada adanya kesenjangan sosial, maraknya perubahan sikap masyarakat yang mengarah ke hal negatif, serta timbulnya potensi konflik di masyarakat. Dari pembahasan ini nampak bahwa pola pengembangan wisata di wilayah pedesaan memiliki dua sisi yang berbeda, dari sisi perekonomian dapat dikatakan menguntungkan namun dari sisi sosial budaya perkembangan wisata dapat merugikan kehidupan masyarakat. Oleh karena itu diperlukan kesadaran dan kesiapan masyarakat menghadapi pengembangan wilayah sebagai destinasi wisata yang akan dikunjungi banyak wisatawan baik lokal maupun wisatatawan mancanegara. Sehingga dengan kesiapan tersebut, masyarakat memiliki pedoman untuk siaga menghadapi berbagai kemungkinan yang terjadi.

Perubahan masyarakat Desa Bejiharjo dalam kurun waktu tahun 2010 sampai dengan 2015 tidak terlepas dari berbagai faktor yang mempengaruhinya. Faktor dalam maupun faktor luar secara cepat atau lambat mendorong terjadinya perubahan masyarakat. Perubahan masyarakat yang terjadi pun tidak hanya dalam satu lingkup aspek saja, melainkan terdapat banyak aspek yang saling terkait dalam mendorong perubahan masyarakat.

Perubahan mata pencaharian masyarakat merupakan salah satu bentuk perubahan yang terjadi dengan adanya kegiatan pengelolaan wisata di Desa Bejiharjo, yang semenjak tahun 2010 telah bertranformasi menjadi Desa Wisata karena kekayaan potensi alamnya. Perubahan yang terjadi dalam aspek ekonomi tersebut merupakan wujud dari adanya proses pemenuhan kebutuhan masyarakat yang sebelum adanya kegiatan pengelolaan wisata ini hanya berpegang pada bidang pertanian, baik sebagai petani, maupun hanya sebagai buruh tani saja. Sehingga kondisi masyarakat sebelum adanya pengelolaan wisata, dapat dikatakan masih di bawah garis kesejahteraan. Dengan pengelolaan wisata saat ini mulai dapat terangkat berkat adanya inisiasi untuk pengelolaan potensi wisata oleh, dari dan untuk masyarakat itu sendiri.

Berbagai faktor yang ada, telah memberikan dampak dan dorongan bagi terciptanya perubahan masyarakat di Desa Bejiharjo.
Salah satu faktor yang berpengaruh adalah faktor dari dalam masyarakat, seperti adanya kemauan untuk berubah karena ketidakpuasan kondisi saat ini, konflik atau pertentangan di masyarakat, atau bahkan penemuan-penemuan baru mampu memberikan kontribusi bagi terciptanya proses perubahan di masyarakat. Selain faktor rasa tidak puas dalam diri masyarakat akan kondisi kesejahteraan saat itu, adanya berbagai inovasi yang mendukung kegiatan pengelolaan wisata juga menjadi salah satu faktor yang berpengaruh terhadap proses perubahan masyarakat. Desa Bejiharjo mengimplementasikannya melalui kegiatan pengoptimalan potensi wilayah yang ada. Yang pada awalnya Desa Wisata Bejiharjo hanya menawarkan destinasi wisata di objek Goa Pindul saja, saat ini sudah berbagai destinasi ada di kawasan Desa Wisata Bejiharjo. Destinasi seperti Body Rafting Kali Oya, Susur Goa, Outbound, hingga Offroad merupakan wujud dari inovasi masyarakat untuk meningkatkan kualitas Desa Wisata Bejiharjo sebagai kawasan destinasi wisata yang lengkap.

beberapa faktor dalam tersebut, perubahan masyarakat juga didorong oleh faktor dari luar seperti pengaruh kebudayaan masyarakat luar. Hal ini sangat beralasan, karena melihat potensi perubahan masyarakat yang dipengaruhi oleh kebudayaan masyarakat luar dapat terjadi kapan saja, mengingat masyarakat lokal selalu berinteraksi dengan masyarakat luar dalam hal ini wisatawan, sehingga berbagai informasi, budaya serta gaya hidup sangat mudah terpengaruh.

Berkaca pada pembahasan tersebut, proses perubahan masyarakat sejatinya dipengaruhi oleh berbagai faktor baik dari dalam maupun luar masyarakat itu sendiri. Sehingga dalam upaya mengarahkan perubahan masyarakat ke arah yang lebih baik, maka diperlukan komitmen bersama terkait proses perubahan ini. Dengan komitmen tersebut, diharapkan tidak ada pihak-pihak tertentu yang diuntungkan atau bahkan dirugikan dalam proses perubahan masyarakat khususnya yang terjadi di Desa Bejiharjo. 
Jurnal Pendidikan dan Pemberdayaan Masyarakat, 4 (1), March 2017 - 11 Ahmad Rofiq

\section{SIMPULAN DAN SARAN}

\section{Simpulan}

Perubahan masyarakat yang terjadi di Desa Bejiharjo terlihat dari adanya pola pemberdayaan masyarakat berbasis pariwisata yang dirintis oleh Pokdarwis Dewa Bejo pada 30 Juni 2010 yang memberikan perubahan pada aspek ekonomi, sosial, budaya dan pendidikan masyarakat Desa Bejiharjo. Pokdarwis Dewa Bejo sebagai agent of change menerapkan konsep pemberdayaan masyarakat dalam pengelolaan potensi wilayah sebagai destinasi wisata yang selanjutnya diikuti beberapa sekretariat wisata dalam pengembangannya.

Dampak yang timbul dari kegiatan wisata yang berjalan sejak tahun 2010 ini terlihat dari segi ekonomi dengan meningkatnya kesejahteraan masyarakat, segi sosial dengan adanya interaksi masyarakat luas memberikan pandangan dan wawasan yang semakin luas bagi masyarakat, dari segi budaya mampu menciptakan momentum untuk melestarikan kekayaan budaya, serta dari segi pendidikan terjadi peningkatan kualitas sumber daya manusia masyarakat Desa Bejiharjo. Sedangkan dari dampak negatif yang timbul dari segi ekonomi adalah adanya persaingan usaha yang terjadi, dari segi sosial terjadi berbagai potensi konflik karena adanya kesenjangan sosial terkait pengelolaan wisata, dari segi budaya meski pelestarian budaya berlangsung namun terkadang hanya sebatas pada pemenuhan kebutuhan wisatawan.

Faktor yang mendorong proses perubahan masyarakat yang terjadi tidak pernah terlepas dari berbagai faktor dalam dan faktor luar yang melatarbelakanginya. Faktor dalam seperti adanya kemauan dalam masyarakat, inovasi dan lain sebagainya menjadi modal penting dalam proses perubahan masyarakat Desa Bejiharjo. Namun semua itu juga tidak terlepas dari faktor luar seperti budaya berbeda wisatawan yang masuk ke wilayah Desa Bejiharjo turut memberikan dorongan terjadinya perubahan masyarakat di Desa Bejiharjo.

\section{Saran}

Bagi masyarakat Desa Bejiharjo sebaiknya memiliki kesiapan dan kesiagaan menghadapi arus wisatawan yang hadir di wilayahnya, agar mampu memiliki pedoman yang kuat sehingga tidak mudah terpengaruh berbagai budaya yang tidak sesuai untuk masyarakat Desa Bejiharjo dan sekitarnya.

Bagi pemerintah diharapkan mampu memberikan pembinaan dan arahan kepada masyarakat, sehingga dapat meminimalisir potensi konflik di masyarakat yang disebabkan karena adanya kesenjangan terkait pola pengelolaan wisata yang ada.

Bagi Kelompok Sadar Wisata (Pokdarwis) yang saat ini berjumlah lebih dari 12 sekretariat, diharapkan ada komunikasi dan kesepakatan bersama agar memiliki standar operasional yang sama, sehingga tidak ada potensi persaingan tidak sehat dalam mendapatkan pengunjung. Serta diharapkan terus mengembangkan inovasi wisata, sehingga tidak monoton untuk paket wisata yang dipasarkan. Dengan kondisi seperti itu maka setiap pokdarwis yang ada akan memiliki keunggulan masing-masing dalam menawarkan paket wisata kepada para pengunjung.

\section{DAFTAR PUSTAKA}

Dinas Pariwisata DIY. (2010). Sadar wisata dan sapta pesona. Yogyakarta: Dinas Pariwisata DIY.

Hadiwijoyo, S. S. (2012). Perencanaan pariwisata perdesaan berbasis masyarakat (Sebuah pendekatan konsep). Yogyakarta: Graha Ilmu. Retrieved from http://grahailmu.co.id/previewpdf/978979-756-894-8-914.pdf

Hannam, K., \& Knox, D. (2010). Understanding tourism: A critical introduction (1 edition). Los Angeles: SAGE Publications Ltd.

Herawati, A., Purwaningsih, A., Pudianti, A., \& Surya, R. V. (2014). Rural tourism community empowerment based on local resources for improving community welfare: Case on Pentingsari Village, Yogyakarta, 


\section{Jurnal Pendidikan dan Pemberdayaan Masyarakat, 4 (1), March 2017 - 12}

Ahmad Rofiq

Indonesia. Review of Integrative Business and Economics Research, 3(2), 88-100. Retrieved from http://sibresearch.org/uploads/3/4/o/9/ 3409718o/riber_b14-071_88-10o.pdf

Horton, P.B. (1980). Sociology. New York: McGraw Hill, Inc.

Miradj, S., \& Sumarno, S. (2014). Pemberdayaan masyarakat miskin, melalui proses pendidikan nonformal, upaya meningkatkan kesejahteraan sosial di Kabupaten Halmahera Barat. Jurnal Pendidikan Dan Pemberdayaan Masyarakat, 1(1), 101-112. http://doi.org/10.21831/JPPM.V1I1.236o

Narayan, D. (2002). Empowerment and Poverty Reduction: A sourcebook. (D. Narayan, Ed.). Washington, DC: The World Bank. http://doi.org/10.1596/o8213-5166-4

Pitana, I.G. \& Gayatri P.G. (2005). Sosiologi pariwisata. Yogyakarta: Andi.
Ruiz-Ballesteros, E., \& Brondizio, E. (2013). Building negotiated agreement: The emergence of community-based tourism in Floreana (Galápagos Islands). Human Organization, 72(4), 323-335. http://doi.org/10.1773o/humo.72.4.4767 $536442 \mathrm{q} 23931$

Soekanto, S. (2012). Sosiologi suatu pengantar. Jakarta: Raja Grafindo Persada.

Soetomo. (2011). Pemberdayaan masyarakat: mungkinkah muncul antitesisnya. Yogyakarta: Pustaka Pelajar.

Sunaryo, B. (2013). Kebijakan pembangunan destinasi pariwisata-konsep dan aplikasinya di Indonesia. Yogyakarta: Gava Media.

Suparjan, H. (2003). Pengembangan masyarakat, (dari pembangunan sampai pemberdayaan). Yogyakarta: Aditya Media. 